\title{
Ovarian Fetiform Teratoma
}

National Cancer Institute

\section{Source}

National Cancer Institute. Ovarian Fetiform Teratoma. NCI Thesaurus. Code C39996.

A rare type of teratoma that arises from the ovary and resembles a malformed fetus. 